\title{
Evaluating the Relationship Between the Carbon and Sulfur Cycles in the Later Cambrian Ocean: An Example from the Port au Port Group, Western Newfoundland, Canada
}

\section{Citation}

Hurtgen, Matthew T., Sara B. Pruss, and Andrew Herbert Knoll. 2009. Evaluating the relationship between the carbon and sulfur cycles in the later Cambrian ocean: An example from the Port au Port Group, western Newfoundland, Canada. Earth and Planetary Science Letters 281(3-4): 288-297.

\section{Published Version}

doi:10.1016/j.epsl.2009.02.033

\section{Permanent link}

http://nrs.harvard.edu/urn-3:HUL.InstRepos:3988784

\section{Terms of Use}

This article was downloaded from Harvard University's DASH repository, and is made available under the terms and conditions applicable to Open Access Policy Articles, as set forth at http:// nrs.harvard.edu/urn-3:HUL.InstRepos:dash.current.terms-of-use\#OAP

\section{Share Your Story}

The Harvard community has made this article openly available.

Please share how this access benefits you. Submit a story. 


\title{
Evaluating the relationship between the carbon and sulfur cycles in the later Cambrian ocean: An example from the Port au Port Group, western Newfoundland, Canada
}

\author{
Matthew T. Hurtgen ${ }^{1}$ \\ Department of Earth and Planetary Sciences, Northwestern University, Evanston, IL 60208, USA \\ Sara Pruss \\ Department of Geology, Smith College, Northampton, Massachusetts 01063, USA \\ Andrew H. Knoll
}

Department of Organismic and Evolutionary Biology, Harvard University, Cambridge, Massachusetts 02138, USA

${ }^{1}$ Corresponding author: matt@earth.northwestern.edu, ph 847.491.7539, fax 847.491.8060 


\section{ABSTRACT}

We present a high-resolution $\delta^{34} \mathrm{~S}$ (sulfate and pyrite) and $\delta^{13} \mathrm{C}_{\text {carbonate }}$ record from the Middle-Upper Cambrian Port au Port Group, a mixed carbonate-siliciclastic succession exposed in western Newfoundland, Canada. The results illustrate systematic $\delta^{34} \mathrm{~S}_{\text {sulfate }}$ shifts of $>15 \%$ o over relatively short stratigraphic intervals (10 m, likely $<1 \mathrm{~m} . \mathrm{y}$.$) , low average \Delta^{34} \mathrm{~S}_{\text {sulfate-pyrite }}$ (ca. $23 \%$ ) and a generally positive coupling between changes in $\delta^{13} \mathrm{C}_{\text {carbonate }}$ and $\delta^{34} \mathrm{~S}_{\text {sulfate. }}$ Together, these results indicate that Middle to Late Cambrian sulfate concentrations were low and that the sulfate reservoir was more sensitive to change than it was in either terminal Neoproterozoic or Cenozoic oceans. However, a simple carbon (C) and sulfur (S) isotope box model of the Late Cambrian ocean illustrates that low sulfate concentrations alone fail to account for the $>15 \%$ $\delta^{34} S_{\text {sulfate }}$ shifts recognized in Port au Port strata. Such large shifts can be generated only if fluctuating oceanic redox is invoked; marine anoxia forces reduced C/S burial and elevated $\Delta^{34} \mathrm{~S}$, driving larger $\delta^{34} S$ changes per mole of organic carbon buried. The conclusion that later Cambrian oceans featured both low sulfate levels and widespread subsurface anoxia supports hypotheses that link fluctuating marine redox conditions in the delayed recovery of skeletal animals and metazoan reefs from late Early Cambrian extinction.

Keywords: Cambrian, sulfate, anoxic, sulfur isotopes, Newfoundland, SPICE 


\section{1. Introduction}

2 The biogeochemical cycles of carbon (C) and sulfur (S) are intimately linked through a

3 variety of feedbacks that operate on timescales of days to millions of years. For example, under

4 anaerobic conditions, some bacteria respire organic matter via sulfate reduction, reducing sulfate

5 to sulfide that then reacts with iron $(\mathrm{Fe})$, assuming it is available, to form pyrite. On much

6 longer timescales, increases in organic carbon (OC) burial can drive an increase in atmospheric

$7 \quad \mathrm{O}_{2}$ concentration which, in turn, facilitates an increase in the extent to which sulfides on land are

8 oxidatively weathered and, ultimately, delivered to the oceans as riverine sulfate. These two

9 processes impose very different relationships between the $\mathrm{C}$ isotope composition of dissolved

10 inorganic carbon (DIC) and the sulfur isotope composition of sulfate in seawater. The former

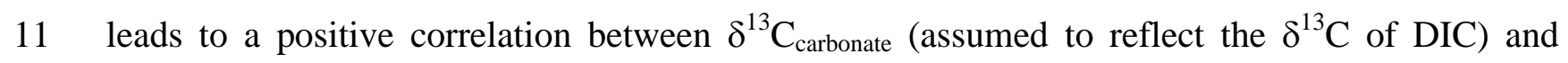

$12 \delta^{34} S_{\text {sulfate }}$ whereas the latter prescribes a long-term negative correlation (e.g., Veizer et al., 1980).

13 Of course, the recognition of either a positive or negative correlation between $\delta^{13} \mathrm{C}_{\text {carbonate }}$ and

$14 \delta^{34} S_{\text {sulfate }}$ depends strongly on the relative residence times of seawater DIC and sulfate, neither of

15 which is well constrained for the Cambrian Period.

16 In the modern ocean, the concentration of DIC is $\sim 2 \mathrm{mM}$ with a residence time of $\sim 100$

17 k.y. (Berner and Berner, 1996). Because of this relatively short residence time, the $\delta^{13} \mathrm{C}$

18 composition of DIC is susceptible to both heterogeneity among the world's ocean basins and

19 short-term (<1 m.y.) change. In contrast, $\delta^{34} \mathrm{~S}_{\text {sulfate }}$ is both homogenous throughout the ocean

20 (Rees, 1978) and buffered against short-term variations due to the relatively high concentration

21 (28 mM) and long residence time ( 25 m.y.) of sulfate in the oceans (Holser et al. 1989). The

22 large inequality in the residence times of DIC and sulfate in the recent geologic past (i.e., the

23 Cenozoic) has made it difficult to evaluate the relationship between these two biogeochemical 
24 cycles that play an important role in regulating Earth's climate (e.g., Kurtz et al., 2003, Paytan et 25 al., 2004).

26 Recent work highlighting the $\delta^{34} S$ composition of carbonate-associated sulfate (CAS) and

27 pyrite suggests that seawater sulfate concentrations increased near the end of the Neoproterozoic

28 Era (Hurtgen et al., 2005; Fike et al., 2006; Halverson and Hurtgen, 2007). However, the

29 chemical composition of fluid inclusions encased in halite (Horita et al., 2002; Lowenstein et al.,

30 2001, 2003; Brennan et al. 2004; Petrychenko et al., 2005) and the recognition of ${ }^{34}$ S-enriched

31 CAS (Kampschulte and Strauss, 2004; Gill et al., 2007), pyrite (Strauss, 1999) and francolite-

32 bound sulfate (Hough et al., 2006) in Lower to Middle Cambrian strata indicate that sulfate

33 levels may have been substantially lower during this time interval relative to both the terminal

34 Neoproterozoic and Cenozoic oceans.

35 Here, we present a detailed $\delta^{13} \mathrm{C}_{\text {carbonate }}$ and $\delta^{34} \mathrm{~S}$ (sulfate and pyrite) record from the

36 Middle-Upper Cambrian Port au Port Group, western Newfoundland, Canada. These sediments

37 record two intervals marked by $\mathrm{C}$ isotope excursions, including a $\sim 4 \%$ positive $\delta^{13} \mathrm{C}_{\text {carbonate }}$

38 excursion that has been identified in a number of localities around the world (the SPICE event,

39 Saltzman et al., 2004). Because of this, the Port au Port succession provides an unusual

40 opportunity to explore the relationship between the marine geochemical cycles of $\mathrm{C}$ and $\mathrm{S}$ during

41 a time interval when the characteristic response times of the DIC and sulfate reservoirs may have

42 been more closely balanced than they are at present. Finally, insights gleaned from the

43 relationship between the C and S cycles during the Cambrian Period may provide an important

44 environmental context for biological changes during this interval, including the 40 m.y. paucity

45 of robust skeletonized fossils in Middle Cambrian through Early Ordovician rocks (e.g., Knoll, 46 2003; Rowland and Shapiro, 2002; Pruss et al., in review). 


\section{2. Background}

492.1 Geochemical cycles of C and S: Mass balance and isotopic considerations

50 The $\delta^{13} \mathrm{C}$ and $\delta^{34} \mathrm{~S}$ composition of seawater DIC and sulfate, respectively, are dictated by

51 the mass and isotopic compositions of $\mathrm{C}$ and $\mathrm{S}$ fluxes into and out of the ocean. For $\mathrm{C}$, the

52 primary input is riverine delivery of DIC resulting from the weathering of crustal rocks. C is

53 removed from marine waters through photosynthesis and subsequent OC burial, as well as by

54 carbonate precipitation and deposition. Analogous to the $\mathrm{C}$ cycle, the primary input of $\mathrm{S}$ (as

55 sulfate) to seawater is riverine delivery resulting from the oxidative weathering of sulfides and

56 dissolution of evaporites (principally calcium sulfates) and carbonates (e.g., CAS) on land.

57 Sulfate is removed from the ocean via evaporite and carbonate deposition, as well as by bacterial

58 sulfate reduction (BSR) and associated pyrite deposition.

59 Balanced changes in the burial of OC and pyrite have played an important role in

60 regulating atmospheric oxygen concentrations through geologic time (Holland, 1973, 1984;

61 Berner and Raiswell, 1983; Kump and Garrels, 1986; Berner 1987). BSR participates in, and so

62 links, the geochemical cycles of $\mathrm{C}$ and $\mathrm{S}$. In the presence of oxygen, OC, produced via

63 photosynthesis in the water column, sinks and is respired aerobically. Once oxygen is

64 consumed, either within the water column or sediments, some microbes decompose OC via BSR,

65 reducing sulfate to sulfide that may react with available iron (Fe) to form sedimentary pyrite.

66 Therefore, increased delivery of OC increases oxygen demand, leading to increased BSR, sulfide

67 production and pyrite formation (Berner and Raiswell, 1983).

68 A kinetic isotope effect accompanies the production of both OC and sulfide during

69 photosynthesis and BSR, respectively. The light isotope (i.e., ${ }^{12} \mathrm{C}$ and ${ }^{32} \mathrm{~S}$ ) is preferentially 
70 removed from the terminal electron acceptor (i.e., $\mathrm{CO}_{2}$ and sulfate) during the production of both

71 OC and sulfide. Within this context, a global increase in OC production and supply to marine

72 sediments should result in increased production of pyrite and, therefore, a positive shift in the C

73 and S isotope compositions of the marine DIC and sulfate reservoirs, respectively. However, as

74 noted above, the characteristic response times of DIC and sulfate strongly influence the rate and

75 magnitude at which the isotope composition of each reservoir can shift.

76 Here, reservoir- and time-dependent mass balance equations for $\delta^{13} \mathrm{C}_{\text {carbonate }}$ and $\delta^{34} \mathrm{~S}_{\text {sulfate }}$

77 (adopted from Kump and Arthur, 1999; Kurtz et al., 2003 and Kah et al., 2004) are used to

78 illustrate how the individual residence times of marine DIC and sulfate influence the degree to

79 which perturbations to the coupled geochemical cycles of $\mathrm{C}$ and $\mathrm{S}$ affect the rate and magnitude

80 of isotopic change. The $\mathrm{C}$ isotope composition of carbonate deposition $\left(\delta^{13} \mathrm{C}_{\text {carbonate }}\right)$ is assumed

81 to reflect the $\delta^{13} \mathrm{C}$ of the DIC pool from which it precipitated and is represented by:

$$
\frac{d}{d t} \delta^{13} C_{\text {carbonate }}=\frac{F_{w c}\left(\delta_{w c}-\delta^{13} C_{\text {carbonate }}\right)-F_{o r g} \Delta^{13} C}{M_{c}}
$$

83 where $F_{w c}$ is the total input flux of $\mathrm{C}$ to the ocean-atmosphere system from weathering, $\delta_{w c}$ is the

84 isotope composition of that weathering component, $F_{\text {org }}$ represents the amount of OC buried,

$85 \Delta \Delta^{13} \mathrm{C}$ represents the average isotope fractionation incurred during the production of OC, and $M_{c}$

86 is the mass of dissolved carbonate in the ocean. Similarly, the S isotope composition of sulfate

87 deposition $\left(\delta^{34} \mathrm{~S}_{\text {sulfate }}\right)$ is assumed to reflect the $\delta^{34} \mathrm{~S}$ of the seawater from which it precipitated 88 and is represented by:

$$
\frac{d}{d t} \delta^{34} S_{\text {sulfate }}=\frac{F_{w s}\left(\delta_{w s}-\delta^{34} S_{\text {sulfate }}\right)-F_{p y} \Delta^{34} S}{M_{s}}
$$


90 where $F_{w s}$ is the total input flux of $\mathrm{S}$ to the ocean-atmosphere system from weathering, $\delta_{w s}$ is the

91 isotope composition of that weathering component, $F_{p y}$ is the total amount of pyrite buried and

$92 \Delta^{34} \mathrm{~S}$ is the average net isotope fractionation between seawater sulfate and pyrite resulting from

93 the processes (e.g., BSR, disproportionation of intermediate $\mathrm{S}$ species, sulfide oxidation)

94 associated with iron sulfide formation, and $M_{s}$ is the mass of sulfate in the ocean. Note, sulfate

95 removed from the oceans via calcium sulfate precipitation in evaporite settings involves minimal

96 isotopic fractionation (0-2.4\%; Ault and Kulp, 1959; Raab and Spiro, 1991) and is excluded

97 from this model. However, large-scale changes in evaporite deposition might significantly

98 influence oceanic $\delta^{34} \mathrm{~S}_{\text {sulfate }}$.

99 Here, we consider the response of $\delta^{13} \mathrm{C}_{\text {carbonate }}$ and $\delta^{34} \mathrm{~S}_{\text {sulfate }}$ to a $50 \%$ increase in $F_{\text {org }}$ and

$100 \quad F_{p y}$ for 1 m.y. (from 2 to 3 m.y. in Fig. 1). Initial conditions were constructed using equations (1)

101 and (2) and mass, fluxes and isotope compositions were adopted from Kurtz et al. (2003) and

102 approximate the Cenozoic $\mathrm{C}$ and $\mathrm{S}$ cycles at steady state (Table 1). The $\mathrm{C}$ and S cycles are

103 linked using a constant C/S burial ratio of 7.7 (Berner and Raiswell, 1983; Raiswell and Berner,

104 1985). The $50 \%$ increase in $F_{\text {org }}$ and $F_{p y}$ manifests as a $2.8 \%$ o positive excursion in $\delta^{13} \mathrm{C}$ but a

105 negligible (0.3\%) shift in $\delta^{34} S_{\text {sulfate. }}$ Of course, this is a simplified model of a more complex

106 system, but it illustrates the importance of concentration and residence time when interpreting

107 perturbations to the coupled C and S cycles at various times in Earth history.

108

109 3. Geologic Setting

110 3.1 The Port au Port Group, Newfoundland, Canada

111 The Middle and Upper Cambrian Port au Port Group is exposed on the south-facing shore

112 of the Port au Port peninsula in western Newfoundland. The succession records Sauk II and 
113 Sauk III transgression and was deposited autochthonously on the southeastern margin of

114 equatorial Laurentia in a subtidal-peritidal setting on a mixed carbonate-clastic platform (Chow 115 and James, 1987; Cowan and James, 1993).

116 The basal unit of the Port au Port Group, the March Point Formation ( 35 m), 117 disconformably overlies siliciclastic rocks of the Lower Cambrian Hawke Bay Formation. 118 March Point lithologies comprise interbedded glauconitic and phosphatic silicilcastics, along 119 with thinly-bedded nodular limestones; they include the deepest water facies preserved in the 120 Middle and Upper Cambrian succession, with some units likely deposited below storm wave 121 base. The overlying Cape Ann Member ( 15 m) of the Petit Jardin Formation contains olive122 colored shales as well as a few thrombolitic carbonate horizons. The overlying Campbell's 123 Member ( 100 m) consists largely of oolites, microbial build-ups, and fine grained carbonate 124 lithologies. The succeeding Big Cove Member, in turn, is a 40-m-thick succession of mostly 125 olive and gray shales with thin limestone beds. The shales are replaced by oolites and microbial 126 build-ups in the overlying Felix Member $(50 \mathrm{~m})$. The Man O' War Member (55 m) is 127 lithologically similar to the underlying Felix Member but contains a greater proportion of 128 siliciclastic sediments. Microbial build-ups are common features throughout the March Point 129 and Petit Jardin formations but skeletal limestones are rare.

130 The March Point Formation preserves a Bolaspidella trilobite fauna, which indicates an

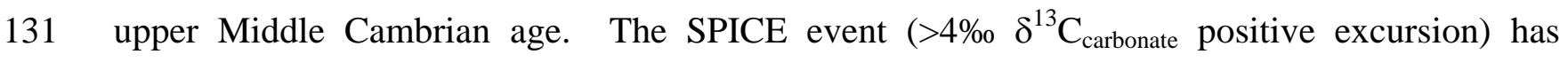
132 previously been identified in this particular section by Saltzman et al. (2004) and is 133 biostratigraphically constrained to the Aphelaspis, Dunderbergia, and Elvinia trilobite zones 134 (Cowan and James, 1993; Saltzman et al., 2004), which are Upper Cambrian (Steptoean) in age. 135 Absolute age dates are absent from Port au Port strata, but given these broad biostratigraphic and 
136 chemostratigraphic constraints, the section of the Port au Port Group addressed in this study was,

137 in all probability, deposited over 5-10 million years.

\section{Methods}

Carbonate-associated sulfate (CAS) and pyrite were extracted using the techniques of

141 Burdett et al. (1989) and Canfield et al. (1986), respectively. S isotope results are reported as per

142 mil (\%) deviations from the S isotope composition of Vienna Canon Diablo Troilite (VCDT),

143 using the conventional delta $\left(\delta^{34} S\right)$ notation; results were generally reproducible to within \pm

144 0.2\%o. C isotope ratios are expressed as \%o deviations relative to VPDB in the standard delta

$145\left(\delta^{13} \mathrm{C}\right)$ notation. Average external precision is estimated to be better than $0.1 \%$. $\mathrm{S}$ and $\mathrm{C}$ isotope 146 data are provided in Supplementary Tables 1 and 2, respectively.

\section{Results}

Carbonate $\mathrm{C}$ isotope values $\left(\delta^{13} \mathrm{C}\right)$ shift systematically through the section, with values

150 ranging from $\sim-4$ to $2 \%$ (Fig. 2). Here, we focus on two intervals marked by sizable $\mathrm{C}$ isotope

151 excursions. The first encompasses the March Point Formation and the Cape Ann and lower

152 Campbell's members of the Petit Jardin Formation. $\delta^{13} \mathrm{C}$ increases from a low of $\sim-2.5 \%$ at the

153 base of the section to an average of $-0.5 \%$ over approximately $30 \mathrm{~m}$, drops to -4\%o over the next

$15430 \mathrm{~m}$ (in the Cape Ann Member) and then rises again to an average of $\sim-0.5 \%$. $\delta^{34} \mathrm{~S}_{\text {sulfate }}$ follows

155 a similar although more exaggerated pattern, with values starting at $30 \%$, falling to $15 \%$ and

156 then increasing to values $>40 \%$ (Fig. 2). The initial drop in $\delta^{34} \mathrm{~S}_{\text {sulfate }}$ precedes the decline in

$157 \delta^{13} \mathrm{C}$ by $\sim 25 \mathrm{~m} . \delta^{34} \mathrm{~S}_{\text {pyrite }}$ generally mimics $\delta^{34} \mathrm{~S}_{\text {sulfate }}$ through this interval; values begin around 
$15815 \%$, decline to around $0 \%$ (one value reaches $-12 \%$ ) before increasing to $>25 \%$. Calculated

$159 \Delta^{34} S\left(\delta^{34} S_{\text {sulfate }}-\delta^{34} S_{\text {pyrite }}\right)$ values through this interval range from 6 to $24 \%$.

160 The second interval includes the upper portion of the Big Cove Member, and the Felix 161 and the Man O' War members of the Petit Jardin Formation. $\delta^{13} \mathrm{C}$ begins at $-1 \%$, falls steadily 162 over the next $35 \mathrm{~m}$ to $-2 \%$, increases to nearly $2 \%$ over the next $30 \mathrm{~m}$ and then shifts to $-3 \%$ 163 over $25 \mathrm{~m}$. This positive excursion, termed the SPICE event, has been recognized in time164 equivalent sections globally, although absolute values vary from location to location (e.g., 165 Saltzman et al., 2000, 2004).

167 no change in $\delta^{13} \mathrm{C}$. Furthermore, $\delta^{34} \mathrm{~S}_{\text {sulfate }}$ values do not shift to markedly heavier values through

168 the SPICE event, but do fall at the upper end of the $\mathrm{C}$ isotope excursion. The $\delta^{34} \mathrm{~S}_{\text {pyrite }}$ record is 169 sparse through this interval (limited pyrite availability) but shows values that range from 0 to $1709 \%$. $\Delta^{34}$ S values begin $>40 \%$ in the upper Big Cove Member and fall to $20 \%$ in the Man O' 171 War Member.

172 While negative $\delta^{13} \mathrm{C}_{\text {carbonate }}$ excursions in particular appear to correspond to lithologic 173 transitions in the Port au Port strata, the relationship between these two variables is not 174 systematic. For example, one negative $\delta^{13} \mathrm{C}$ excursion is associated with relatively shallow 175 deposition within the upper Campbell's Member while another is linked with the deeper water 176 (relative to the upper Campbell's Member) facies of the Cape Ann Member. The large variations in $\delta^{34} S_{\text {sulfate }}$ evident in parts of the Port au Port strata warrant 178 consideration of secondary processes that could affect the $\mathrm{S}$ isotope composition of CAS. $179 \delta^{18} \mathrm{O}_{\text {carbonate }}$ is a useful indicator of geochemical alteration as ${ }^{18} \mathrm{O}$-depleted signatures are often 180 attributed to post-depositional alteration resulting from isotopic exchange with meteoric fluids 
181 (e.g., Given and Lohmann, 1985). The absence of any correlation between $\delta^{34} \mathrm{~S}_{\mathrm{CAS}}$ and

$182 \delta^{18} \mathrm{O}_{\text {carbonate }}$ suggests that post-depositional processes did not alter the $\mathrm{S}$ isotope composition of

183 CAS substantially. Furthermore, to a first order, $\delta^{34} \mathrm{~S}_{\text {pyrite }}$ is dictated by seawater sulfate $\delta^{34} \mathrm{~S}$.

184 Therefore, the large and sympathetic shits in $\delta^{34} \mathrm{~S}_{\text {sulfate }}$ and $\delta^{34} \mathrm{~S}_{\text {pyrite }}$ (particularly in the lower part

185 of the section) supports the contention that $\delta^{34} \mathrm{~S}_{\text {sulfate }}$ is recording a primary seawater signal.

187 6. Discussion

$188 \quad 6.1$ Ediacaran and Cambrian S isotopes and marine sulfate levels

Several lines of evidence suggest that an Ediacaran increase in the oxidation state of the

190 ocean-atmosphere system led, perhaps for the first time in Earth history, to elevated seawater

191 sulfate concentrations. This evidence includes, but is not limited to, a shift in the abundance of

192 redox-sensitive elements (Canfield et al., 2007; Scott et al., 2008) and a substantial rise in the S

193 isotope difference between seawater sulfate and contemporaneously deposited sedimentary

194 pyrite $\left(\Delta^{34} S\right)$ (Canfield and Teske, 1996; Hurtgen et al., 2005; Fike et al., 2006; Halverson and 195 Hurtgen, 2007; McFadden et al., 2008). Importantly, the extent of fractionation between 196 seawater sulfate and co-occurring sedimentary pyrite is controlled in large part by sulfate 197 availability. And, the amount of oxygen in the ocean atmosphere system is believed to exert a 198 primary control on marine sulfate levels because the primary source of seawater sulfate is 199 riverine input derived in part from the oxidative weathering of pyrite (e.g., Canfield, 2004). This

200 increase in $\Delta^{34} \mathrm{~S}$ (and by inference an increase in Earth surface oxygen levels) is evident in 201 Figure 3 and marked by a substantial decline in $\delta^{34} S_{\text {pyrite }}$ through the second half of the Ediacaran 202 Period, as recorded in sediments from Oman (Fike et al. 2006). $\Delta^{34}$ S decreases at the very end of 203 the Ediacaran period (Fike and Grotzinger, 2008) before increasing again in the earliest 
204 Cambrian. [Note that this composite $\delta^{34} \mathrm{~S}$ (sulfate and pyrite) and $\delta^{13} \mathrm{C}$ record does not include 205 all available data for the terminal Neoproterozoic due to poor age constraints for some samples.] 206 Sulfate levels may have dropped substantially during Early to Middle Cambrian time as 207 suggested by the chemical composition of fluid inclusions in halite (Horita et al., 2002; 208 Lowenstein et al., 2001, 2003; Brennan et al. 2004; Petrychenko et al., 2005) and ${ }^{34}$ S-enriched 209 CAS (Kampschulte and Strauss, 2004; Gill et al., 2007), pyrite (Strauss, 1999) and francolite210 bound sulfate (Hough et al., 2006) in Early to Middle Cambrian sediments. The recognition of a 211 marked decrease in $\Delta^{34} \mathrm{~S}$ would corroborate the notion that marine sulfate levels fell at this time

212 (see discussion below). However, as Figure 3 illustrates, it is difficult to evaluate $\Delta^{34} \mathrm{~S}$ through 213 this interval due to a lack of previously published $\delta^{34} S_{\text {sulfate }}$ and $\delta^{34} S_{\text {pyrite }}$ generated in tandem 214 from the same stratigraphic section.

$2166.2 \delta^{34} S_{\text {sulfate, }} \delta^{34} S_{\text {pyrite, }} \Delta^{34} S$ and Middle to Late Cambrian sulfate availability

217 The S isotope results from this study support the fluid inclusion (Horita et al., 2002;

218 Lowenstein et al., 2001, 2003; Brennan et al. 2004; Petrychenko et al., 2005) and previous S 219 isotope work (Strauss, 1999; Kampschulte and Strauss, 2004; Hough et al., 2006; Gill et al., 220 2007) and suggest that sulfate concentrations in the Middle to Late Cambrian ocean were low 221 relative to terminal Neoproterozoic and modern values. The large and systematic shifts in $222 \delta^{34} S_{\text {sulfate }}(>25 \%)$ occur over relatively short geological timescales $(<\sim 2$ m.y.; based on the 223 assumption that the entire section of Port au Port Group addressed in this study was deposited 224 over 5 to 10 million years) and are consistent with a seawater sulfate reservoir that was sensitive 225 to relatively short-term environmental perturbations (e.g., changes in pyrite burial and/or $\Delta^{34} \mathrm{~S}$ ).

226 Moreover, $\delta^{34} S_{\text {pyrite }}$ shifts in unison with $\delta^{34} S_{\text {sulfate }}$ through much of the section, but especially 
227 through the March Point Formation and Cape Ann and Campbell's members of the Petit Jardin

228 Formation. To a first order, $\delta^{34} S_{\text {pyrite }}$ is dictated by seawater sulfate $\delta^{34} S$ and sympathetic 229 changes in $\delta^{34} S_{\text {sulfate }}$ and $\delta^{34} S_{\text {pyrite }}$ supports the contention that $\delta^{34} S_{\text {sulfate }}$ is changing over 230 relatively short stratigraphic distances (at least in this particular setting).

231 The S isotope difference between marine sulfate and contemporaneously deposited 232 sedimentary pyrite $\left(\Delta^{34} \mathrm{~S}\right)$ provides further evidence for lower sulfate levels during this time 233 interval. The kinetic isotope effect associated with BSR, documented through experimental 234 studies (i.e., Detmers et al., 2001) and in natural systems (Habicht and Canfield, 1997; Habicht 235 and Canfield, 2001), leads to a fractionation of 2-46\%. In large part, the magnitude of this 236 fractionation is controlled by sulfate availability; larger fractionations are typically expressed 237 under non-limiting sulfate concentrations where microbes have a large reservoir of sulfate that 238 allows them to dissimilate ${ }^{32} \mathrm{~S}$ preferentially. Smaller fractionations occur when sulfate is 239 limiting because sulfate-reducing microbes can alter the local sulfate reservoir (water column or 240 sediments) by extracting ${ }^{32} \mathrm{~S}$ in the production of sulfide, thereby increasing the $\delta^{34} \mathrm{~S}$ composition 241 of residual sulfate and subsequently generated pyrite. Moreover, the capacity of sulfate-reducing 242 microbes to dissimilate ${ }^{32} \mathrm{~S}$ in preference to ${ }^{34} \mathrm{~S}$ decreases as sulfate concentrations fall below $243 \sim 50-200 \mu \mathrm{M}$ (Habicht et al., 2002). Therefore, the overall effect of sulfate limitation is lower $244 \Delta^{34} \mathrm{~S}$.

245 In order to achieve $\Delta^{34} \mathrm{~S}>46 \%$, BSR must be accompanied by fractionations incurred 246 during the disproportionation of intermediate $\mathrm{S}$ species (e.g., $\mathrm{S}^{0}, \mathrm{~S}_{2} \mathrm{O}_{3}{ }^{2-}$; Jørgensen, 1990) that 247 results in sulfide depleted in ${ }^{34} \mathrm{~S}$ relative to the initial reactant by an additional 7-20\% (Canfield 248 and Thamdrup, 1994; Cypionka et al., 1998; Habicht et al., 1998; Böttcher et al., 2001). 
249 Through repeated sulfide oxidation and disproportionation cycles, sulfide isotope values can 250 become depleted relative to sulfate by significantly more than $46 \%$.

251 While variable, Port au Port Group $\Delta^{34}$ S values average 23\%; all but three of the values

252 fall between 15 and 30\%o and none exceed 46\%. This average is both lower than the assumed

253 modern average value (35\%; Garrels and Lerman, 1984) and average values published for the

254 latest Neoproterozoic ( $\sim 35 \%$; Fike et al., 2006). However, $<46 \%$ o values do not necessarily

255 indicate that S disproportionation was absent (i.e., Hurtgen et al., 2005, Johnston et al. 2005);

256 rather, they may relate to the efficiency with which sulfide is removed by reaction with $\mathrm{Fe}^{2+}$,

257 itself a function of seawater $\mathrm{P}_{\mathrm{O} 2}$ (Hurtgen et al., 2005). It is important to note that the $\mathrm{S}$ isotope

258 composition of sedimentary pyrite is strongly influenced by local conditions and therefore these

259 modest $\Delta^{34} \mathrm{~S}$ values are not necessarily representative of a Middle to Late Cambrian average.

260 However, the low $\Delta^{34} \mathrm{~S}$ values in combination with the rapid shifts in $\delta^{34} \mathrm{~S}_{\text {sulfate }}$ and $\delta^{34} \mathrm{~S}_{\text {pyrite }}$ over

261 relatively short stratigraphic distances strongly support the notion that this particular basin

262 contained low sulfate concentrations.

263

2646.3 Relationship between $\delta^{13} C, \delta^{34}$ S, and sulfate concentrations

265 Very generally, $\delta^{13} \mathrm{C}$ and $\delta^{34} \mathrm{~S}_{\text {sulfate }}$ are positively correlated through the Port au Port

266 strata, which suggests that the residence times of DIC and sulfate may have been roughly

267 comparable, at least in this basin. These positively correlated C and S isotope shifts may have

268 been driven by changes in OC burial and subsequent sympathetic changes in pyrite burial.

269 However, two deviations from the positive correlation exist and suggest, not surprisingly, that

270 the relationship between these two elemental cycles is more complex than outlined above. 
The most obvious deviation occurs during the SPICE event, where the $\sim 4 \%$ positive C

272 isotope excursion that straddles the Felix and Man O’ War members is not accompanied by a

273 significant shift in $\delta^{34} \mathrm{~S}_{\text {sulfate }}$ (or $\delta^{34} \mathrm{~S}_{\text {pyrite}}$ ). While only five $\delta^{34} \mathrm{~S}_{\text {sulfate }}$ values were determined

274 through the SPICE event, it is important to note that one sample is coincident with the peak of

275 the $\delta^{13} \mathrm{C}$ excursion. This pattern is very similar to that generated by the model we used to

276 ascertain changes in the coupled C and S system for the Cenozoic (Fig. 1); it would seem to

277 suggest that the residence time of sulfate in the ocean was much greater than that of DIC and

278 perhaps not drastically different from the modern ocean. However, the rapid $\delta^{34} \mathrm{~S}_{\text {sulfate }}$ shifts that

279 are present throughout this section (Fig. 2) are consistent with a sulfate reservoir more sensitive

280 to isotopic modification and it is unlikely that sulfate levels would increase through the SPICE

281 event given that the positive $\delta^{13} \mathrm{C}$ excursion is thought to have been driven by an increase in OC

282 burial (Saltzman et al., 2004), providing more fuel for BSR. Moreover, in a separate section of

283 equivalent age deposited in an epicontinental sea elsewhere in Laurentia (Nevada), $\delta^{34} \mathrm{~S}_{\text {sulfate }}$ does

284 exhibit a positive excursion (>10\%) through the SPICE interval (Gill et al., 2007) and pre-

285 SPICE event $\delta^{13} \mathrm{C}$ and $\delta^{34} \mathrm{~S}$ are elevated relative to Newfoundland strata. These contrasting

286 datasets from central and southern Laurentia suggest that the ocean was heterogeneous with

287 respect to $\delta^{34} \mathrm{~S}_{\text {sulfate }}$ (and $\delta^{13} \mathrm{C}$ ) and so further supports the contention that Cambrian seawater

288 sulfate concentrations were low relative to modern values.

If marine sulfate concentrations were substantially lower in the Cambrian, why is it that

290 positive $\delta^{13} \mathrm{C}$ excursions are recognized globally and $\delta^{34} \mathrm{~S}_{\text {sulfate }}$ excursions are not? One possible

291 explanation is that the residence time of seawater sulfate through this interval was significantly

292 lower than that of DIC, allowing for greater $\delta^{34} \mathrm{~S}_{\text {sulfate }}$ heterogeneity throughout the world oceans.

293 If we assume the residence time of DIC approximated modern values ( 100 k.y.), and S fluxes 
294 into and out of the ocean were similar to Cenozoic estimates $\left(\sim 1.5 \times 10^{18}\right.$ moles/m.y.; Kurtz et 295 al., 2003), then sulfate levels must have been substantially $<\sim 100 \mu \mathrm{M}$. If S fluxes into and out 296 of the ocean scaled proportionally with the marine sulfate reservoir and were lower during the 297 Cambrian, sulfate concentrations would have been even lower. Conversely, if the residence time 298 of DIC in the Cambrian ocean were higher than modern values (e.g., Berner, 2006), sulfate levels 299 could have been higher. For example, if the residence time of DIC in the Cambrian ocean was 300500 k.y. ( $\sim 5 \mathrm{x}$ modern levels) and S fluxes into and out of the ocean were similar to Cenozoic 301 estimates, then sulfate levels must have been $<525 \mu \mathrm{M}$ in order for the residence time of sulfate 302 to be less than the residence time of DIC. Again, if S fluxes into and out of the ocean scaled 303 proportionally with sulfate levels and were lower, sulfate concentrations would have been 304 substantially $<525 \mu \mathrm{M}$. These sulfate concentrations are well below those estimated from fluid 305 inclusions encased in Cambrian halite (e.g., 5 - 12 mM; Horita et al., 2002; Lowenstein et al., 306 2003, Brennan et al. 2004, Petrychenko et al., 2005). However, given the number of unknowns 307 (e.g., DIC residence time, S fluxes into and out of the ocean) we cannot rule out the possibility 308 that the residence time of seawater sulfate was less than the residence time of DIC during this 309 time.

310 Alternatively, the apparent heterogeneity in $\delta^{34} \mathrm{~S}_{\text {sulfate }}$ may indicate that one or both of 311 these environments (Newfoundland and/or Nevada) were somewhat restricted and not fully 312 tracking the $\mathrm{S}$ isotope composition of the global ocean. If so, however, why is it that sediments 313 from both localities record the $\delta^{13} \mathrm{C}$ excursion across the SPICE event but the $\delta^{34} \mathrm{~S}_{\text {sulfate }}$ excursion 314 is expressed only in Nevada? One explanation may be linked to carbon exchange between 315 marine surface waters and the atmosphere. Over relatively short geologic timescales ( $<10^{4}$ y.r.), 316 the $\delta^{13} \mathrm{C}$ composition of bulk atmospheric $\mathrm{CO}_{2}$ is governed by carbon exchange with the 
317 terrestrial biosphere and DIC in marine surface waters (e.g., Indermühle et al. 1999). Since

318 vascular land plants had not evolved in the Cambrian (e.g., Edwards 1979), the C isotope

319 composition of atmospheric $\mathrm{CO}_{2}$ would have largely been dictated by equilibrium isotope

320 fractionations associated with air-sea gas exchange between the atmosphere and ocean (Mook,

321 1986). If $\delta^{13} \mathrm{C}_{\text {DIC }}$ of marine surface waters were driven to substantially higher values for

322 hundreds of thousands of years—as they were during the SPICE event (Saltzman et al. 2004)—

323 the $\delta^{13} \mathrm{C}$ composition of atmospheric $\mathrm{CO}_{2}$ should have also increased by a corresponding, albeit

324 offset, amount. This ${ }^{13} \mathrm{C}$-enriched atmospheric $\mathrm{CO}_{2}$ could then influence the surface waters of

325 basins not well connected to the open ocean and essentially transfer the $\delta^{13} \mathrm{C}_{\text {carbonate }}$ excursion 326 generated in the open ocean to more restricted settings. The absolute $\delta^{13} \mathrm{C}$ values of carbonates

327 surrounding the SPICE event in Newfoundland and Nevada are not the same but the magnitude

328 of the C isotope excursion is remarkably similar ( $4 \%$ ). No similar mechanism is known for

329 expressing $\delta^{34} S_{\text {sulfate }}$ excursions generated in the open ocean to more restricted settings.

330 However, in order for the C isotope composition of DIC in an isolated basin to be buffered to the

331 atmosphere, the amount of $\mathrm{C}$ residing as DIC in the restricted basin must have been substantially

332 lower than the amount of $\mathrm{CO}_{2}$ in the Cambrian atmosphere. Of course, neither the size of the

333 DIC reservoir nor Cambrian $p \mathrm{CO}_{2}$ levels is known, and therefore, it is difficult to evaluate the 334 reasonableness of this explanation.

335 The second instance where C and S isotopes appear to deviate from positively correlated 336 changes is in the March Point Formation where a $15 \%$ decrease in $\delta^{34} S_{\text {sulfate }}$ (and $\delta^{34} S_{\text {pyrite) }}$ ) 337 precedes a $\sim 4 \%$ fall in $\delta^{13} \mathrm{C}$ (Fig. 2). This is an intriguing result and again may indicate that 338 sulfate levels were sufficiently low in this basin and that the characteristic response time for $339 \delta^{34} \mathrm{~S}_{\text {sulfate }}<\delta^{13} \mathrm{C}_{\text {DIC }}$. In other words, a decrease in OC burial may have influenced $\delta^{34} \mathrm{~S}_{\text {sulfate }}$ more 
340 rapidly than $\delta^{13} \mathrm{C}$ by reducing pyrite burial rates. While time constraints are poor through this

341 interval, the lag time between the initial $\delta^{34} \mathrm{~S}$ drop and $\delta^{13} \mathrm{C}$ fall is represented by $\sim 25 \mathrm{~m}$ of

342 section and likely represents too much time ( $>10^{4}$ y.r.) for this to be reasonable if the residence

343 time of DIC was between 100 and 500 k.y. Alternatively, the $\delta^{34} S_{\text {sulfate }}$ decline may not have

344 been directly and/or immediately linked to perturbations of the C cycle. For example, $\delta^{34} \mathrm{~S}_{\text {sulfate }}$

345 variations are typically attributed to changes in pyrite burial rates facilitated by changes in OC

346 availability. However, in the modern ocean, pyrite burial efficiency is quite low; as much as

$34795 \%$ of sulfide generated during BSR is reoxidized to sulfate and intermediate S species

348 (Jørgensen et al., 1990). Within this context, pyrite burial rates may oscillate substantially if the

349 percentage of BSR-generated sulfide that is oxidized to sulfate and intermediate S species

350 varies — even if global rates of BSR remain constant.

351 Turchyn and Schrag (2004) argued that fluctuations in the oxygen isotope composition of

352 seawater sulfate over the last 10 m.y. can be attributed to changes in the extent and means by

353 which sulfide has been reoxidized on continental margins. These high frequency changes in

354 pyrite burial efficiency have had little to no effect on $\delta^{34} \mathrm{~S}_{\text {sulfate }}$ over the last $10 \mathrm{~m}$.y. due to the

355 large residence time of sulfate over this time interval (e.g., Paytan et al., 1998). However, if the

356 Cambrian ocean had much lower sulfate concentrations, changes in the balance between sulfide

357 production (via BSR) and reoxidation could have affected $\delta^{34} \mathrm{~S}_{\text {sulfate }}$ considerably on shorter $(<1$

358 m.y.) geological timescales. An important control on the extent of sulfide reoxidation is oxygen

359 availability in the marine system and it has been argued that globally extensive black shale

360 deposition in the Middle and Upper Cambrian resulted from poor ventilation of the deep oceans

361 during a greenhouse climate (Berry and Wilde, 1978). The $\delta^{34} \mathrm{~S}$ drop that proceeds the $\delta^{13} \mathrm{C}$ fall

362 in the March Point Formation may have been induced by changes in pyrite burial efficiency 
363 facilitated by subtle changes in Cambrian marine redox that influenced the S cycle before (and/or

364 to a greater extent than) the C cycle. This discussion is expanded below. More specifically, we

365 explore how oceanic redox might influence the C/S burial ratio and $\Delta^{34} \mathrm{~S}$ on a global scale in a

366 way that would facilitate larger $\delta^{34} S_{\text {sulfate }}$ excursions per mole of OC burial.

Here, we utilize the simple reservoir- and time-dependent mass balance equations for

$370 \delta^{13} \mathrm{C}$ and $\delta^{34} \mathrm{~S}_{\text {sulfate }}$ (equations 1 and 2) to understand better the relationship between sulfate

371 residence time and $\delta^{34} S_{\text {sulfate }}$ response to perturbations to the Cambrian $\mathrm{C}$ cycle. More

372 specifically, how low must sulfate concentrations have been (assuming Cenozoic inputs and

373 outputs of $S$ to and from the marine system) to generate the $>10 \% \delta^{34} S_{\text {sulfate }}$ shifts expressed in

374 the Cambrian data presented in Figure 2 and yet remain consistent with the modest, but not

375 negligible, $\Delta^{34} \mathrm{~S}$ values? In the following simulations, we assume the $>10 \%$ o $\delta^{34} \mathrm{~S}_{\text {sulfate }}$ variations

376 were global in extent; however, as already discussed, it is possible that the Newfoundland $\delta^{34} \mathrm{~S}$

377 signal records local perturbations not necessarily linked to the global ocean. Nonetheless, this

378 exercise highlights important aspects of the relationships among $\delta^{13} \mathrm{C}, \delta^{34} \mathrm{~S}$, and $\Delta^{34} \mathrm{~S}$ in a low 379 sulfate ocean.

380 The sensitivity of $\delta^{34} \mathrm{~S}_{\text {sulfate }}$ to a stepwise, $50 \%$ increase in $F_{\text {org }}$ and $F_{\mathrm{py}}$ for 1 m.y. (during 381 the interval 2 to 3 m.y., represented by gray band) is explored under varying initial sulfate 382 concentrations (Fig. 4). As earlier, initial conditions were constructed using mass, flux and 383 isotope compositions believed to represent Cenozoic C and S cycles (Kurtz et al., 2003). 384 However, here we prescribe lower initial sulfate levels (0.28 mM, $1.9 \mathrm{mM}$ and $3.5 \mathrm{mM})$ and a 385 lower $\Delta^{34}$ S (25\% rather than 35\%) that approximates the average recorded in Port Au Port 
386 Group sediments and is more consistent with a low sulfate ocean. The reduced $\Delta^{34} \mathrm{~S}$ forces a 387 lower steady state $\delta^{34} S_{\text {sulfate }}$ value (17.7\%) but more importantly it reduces the magnitude of $388 \delta^{34} \mathrm{~S}_{\text {sulfate }}$ excursions generated per mole of OC buried. The C and S cycles are again linked using 389 a constant C/S burial ratio of 7.7. [Raiswell and Berner (1986) challenged constant C/S and we 390 explore the consequences of relaxing this assumption below.] Although not shown in Figure 4, 391 the 50\% increase in $F_{\text {org }}$ forces a 2.8\%o positive excursion in $\delta^{13} \mathrm{C}$ as shown in Figure 1.

392 The model results indicate that even at very low initial sulfate concentrations (280 $\mu \mathrm{M}, \tau$ $393=0.27 \mathrm{~m} . \mathrm{y}$.$) , a 50 \%$ increase in OC and pyrite burial prompts only an $\sim 5 \%$ o $\delta^{34} \mathrm{~S}_{\text {sulfate }}$ excursion. 394 In three of the four runs, $\Delta^{34} S$ was held constant at 25\%. However, in run 1a (Fig. 4), we 395 include a stepwise decrease in $\Delta^{34} S$ from 25 to $15 \%$ once sulfate concentrations drop to $<200$ $396 \mu \mathrm{M}$ (e.g., Habicht et al., 2002). This forces $\delta^{34} \mathrm{~S}_{\text {sulfate }}$ to decrease abruptly within the OC burial 397 event and ultimately bring about an 8\%o decline over 1 m.y. This underscores an interesting 398 aspect of S cycling in low sulfate oceans: the sensitivity of $\Delta^{34} \mathrm{~S}$ to fluctuating ocean chemistries 399 and its influence on the $\mathrm{S}$ isotope evolution of seawater sulfate.

400 Previous work suggests that the Middle to Upper Cambrian ocean may have been more 401 susceptible to at least regional anoxia. Berry and Wilde (1978) argued that extensive black shale 402 deposition in the Cambrian resulted from poor ventilation of the deep oceans due to minimal sea 403 ice formation at high latitudes. Similarly, Saltzman (2005) suggested that extended ( $>10^{7}$ y.r.) 404 periods of relative $\delta^{13} \mathrm{C}$ stability found in much of the Middle and Upper Cambrian resulted from 405 nitrogen limitation in a greenhouse climate that promoted reduced $\mathrm{O}_{2}$ solubility in marine waters 406 and increased denitrification as result of water column anoxia. Furthermore, Raiswell and 407 Berner (1986) found that C/S ratios in Cambrian aged marine shales were lower $(\sim 0.5)$ than 
408 those recorded during any other period during the Phanerozoic (modern $=2.8$ ). They attributed 409 reduced C/S to euxinic conditions.

410 If the chemocline were raised into the water column during times of enhanced OC 411 production in the Cambrian, syngenetic (water column) pyrite formation may have occurred. 412 This has important implications for evaluating the relationship between the Cambrian C and S 413 isotope record for two reasons. First, sediments deposited under euxinic conditions are 414 characterized by reduced C/S as result of syngenetic pyrite formation that is decoupled from the 415 amount of OC buried in the sediments (Leventhal, 1983; Raiswell and Berner, 1985). Under 416 these circumstances, Fe is often the limiting factor in pyrite formation rather than OC (Raiswell 417 and Berner, 1985). Second, if a significant fraction of pyrite ultimately buried in the sediments 418 formed syngenetically, $\Delta^{34} \mathrm{~S}$ values may have shifted to significantly higher values. This is 419 because sulfate-reducing bacteria have a much larger reservoir of sulfate from which to 420 dissimilate the lighter ${ }^{32} \mathrm{~S}$ versus ${ }^{34} \mathrm{~S}$ (e.g., Lyons, 1997; the effect is seen in mid-Proterozoic S 421 isotope data of Shen et al., 2003). Within this context, if the Cambrian ocean was susceptible to 422 periods of euxinia, C/S ratios likely decreased and $\Delta^{34} \mathrm{~S}$ may have increased (assuming sulfate 423 levels were not brought too low during the event), permitting much larger $\mathrm{S}$ isotope shifts in 424 seawater sulfate per mole of $\mathrm{C}$ buried.

425 As earlier, the sensitivity of $\delta^{34} \mathrm{~S}_{\text {sulfate }}$ to a stepwise, $50 \%$ increase in $F_{\text {org }}$ for 1 m.y. is 426 explored under varying initial sulfate concentrations (Fig. 5). However, in order to account for 427 an increase in syngenetic pyrite formation resulting from anoxia, $F_{\text {py }}$ increases $100 \%$ through the 428 OC burial event and $\Delta^{34} \mathrm{~S}$ increases from 25 to $30 \%$. As a result, larger $\delta^{34} \mathrm{~S}_{\text {sulfate }}$ excursions are 429 expressed per mole of OC buried. A $\sim 13 \%$ o $\delta^{34} \mathrm{~S}_{\text {sulfate }}$ increase is generated over 1 m.y. when 430 initial sulfate levels are set at $700 \mu \mathrm{M}(\tau=0.67$ m.y. $)$. 
Given these preliminary modeling results, it appears that $>10 \%$ global $\delta^{34} S_{\text {sulfate }}$ shifts

432 may be generated by OC burial events ( $F_{\text {org }}$ increases by $50 \%$ ) at sulfate levels approaching 1

$433 \mathrm{mM}$ if $\mathrm{C} / \mathrm{S}$ and $\Delta^{34} \mathrm{~S}$ are allowed to fluctuate as a result of water column anoxia. Of course, this

434 is a crude estimate that assumes we have some control on the residence time of DIC in the

435 Cambrian as well as S fluxes into and out of the ocean-which we do not. In fact, if S fluxes

436 into and out of the ocean were scaled proportionally with the marine sulfate reservoir and were

437 lower in the Cambrian, the residence time of sulfate would have been higher (similar to Cenozoic

438 values), making it more difficult to generate $>10 \% \delta^{34} \mathrm{~S}_{\text {sulfate }}$ excursions (e.g., Fig. 1). We are

439 not necessarily advocating a particular sulfate concentration for Late Cambrian seawater.

440 Rather, we are suggesting that sulfate levels were low relative to modern values, that decreased

441 residence time for $\mathrm{S}$ and, possibly, increased residence time for $\mathrm{C}$ are necessary to understand the

442 relationships between $\mathrm{C}$ and S isotopes, and perhaps most importantly, basinal anoxia must be

443 invoked in the models to reproduce the geochemical signatures preserved in the Port au Port

444 strata. Furthermore, the interpretations developed in this study are only based on two sections in

445 relatively shallow seas bordering Laurentia (Newfoundland and Nevada; Gill et al., 2007).

446 Future work should focus on reconstructing the temporal and spatial evolution of $\delta^{13} \mathrm{C}$ and $\delta^{34} \mathrm{~S}$

447 (sulfate and pyrite) through multiple sections of early Paleozoic strata in order to constrain the 448 mechanistic details underpinning the geochemical evolution of the $\mathrm{C}$ and S cycles. Nonetheless, 449 these two data sets, coupled with simple modeling results, do highlight some interesting 450 dynamics relating OC burial, sulfate concentrations, ocean redox, $\Delta^{34} \mathrm{~S}$ and ultimately $\delta^{34} \mathrm{~S}_{\text {sulfate. }}$

$452 \quad 6.5 \quad$ Relationships among sulfate levels, atmospheric $\mathrm{O}_{2}$ and Cambrian life 
The Early Paleozoic represents one of the most dynamic times in the history of complex

454 life. Within the first 25 million years of the Cambrian Period, animals with mineralized 455 skeletons diversified and the first metazoan reefs were established. This major diversification, 456 known as the Cambrian Explosion, was disrupted by major extinctions near the end of the Early 457 Cambrian (e.g., Zhuravlev and Wood, 1996). These extinctions decimated the archaeocyathids 458 and other massively calcified reef builders and also marked the last appearances of many so459 called small shelly fossils (but see Porter, 2004, for discussion of taphonomic bias). For the 460 ensuing 40 million years of the Middle to Late Cambrian and earliest Ordovician, the 461 abundance of skeletons was low in marine carbonates (Li and Droser, 1997, 1999), animal reefs 462 were absent (Rowland and Shapiro, 2002) and turnover rates were unusually high (Bambach et 463 al., 2004). What makes this interval enigmatic is that it postdates the origins of both the major 464 animal body plans and the evolution of calcified skeletons within many of them, but predates the 465 major Ordovician radiation that established skeletons as major sinks for calcium carbonate.

466 If an increase in the oxidation state of the coupled ocean-atmosphere system paved the 467 way for the evolution and radiation of macroscopic Metazoa in the Ediacaran (e.g., Knoll and 468 Carroll, 1999; Canfield et al., 2007; Fike et al., 2006), it is reasonable to ask if changes in marine 469 redox profiles during the Early to Middle Cambrian and into the Ordovician governed the demise 470 and delayed recovery of skeletonized animals (e.g., Zhuravlev and Wood, 1996; Pruss et 471 al.,2007). Several lines of evidence suggest that marine waters were more susceptible to 472 episodes of anoxia during this time, including extensive black shale deposition (Berry and Wilde, 473 1978), increased seawater temperatures and therefore lower $\mathrm{O}_{2}$ solubility (Berry and Wilde, 474 1978; Saltzman 2005; Trotter et al., 2008), and reduced C/S in Cambro-Ordovician marine shales 475 (Raiswell and Berner, 1986). Furthermore, the C and S isotope models presented in this study 
476 indicate that fluctuating water column anoxia in a low sulfate ocean generates the largest $\delta^{34} \mathrm{~S}$

477 excursions per mole of OC produced/buried consistent with the $\delta^{13} \mathrm{C}$ and $\delta^{34} S_{\text {sulfate }}$ shifts

478 expressed in the Port au Port carbonates of Newfoundland. Collectively, these results suggest

479 that reduced oxygen levels in subsurface water masses may have played a significant role in late

480 Early Cambrian extinction and the delayed recovery of animal reefs and skeletonized animals,

481 arguably by decreasing the saturation state of surface waters with respect to carbonate minerals

482 (Fischer et al. 2007, Higgins and Schrag, 2007; see Pruss et al., 2007, for explicit discussion of

483 Cambro-Ordovician oceans). Continuing geochemical research will help to determine the

484 environmental context of major events in both Cambrian and Ordovician skeletal evolution.

485

\section{Conclusions}

A significant increase in $\Delta^{34} \mathrm{~S}$, as recorded in terminal Neoproterozoic rocks, suggests that an increase in the oxidation state of the ocean-atmosphere system facilitated an increase in seawater sulfate concentrations just prior to the appearance of the Ediacaran Fauna (Fike et al., 2006). Sulfate levels, however, may have dropped substantially during the Early to Middle

491 Cambrian (Horita et al., 2002; Lowenstein et al., 2001, 2003; Brennan et al., 2004; Kampschulte 492 and Strauss, 2004; Petrychenko et al., 2005; Hough et al., 2006; Gill et al., 2007). S isotope 493 results presented in this study support these findings; reduced $\Delta^{34} \mathrm{~S}$, large $\delta^{34} \mathrm{~S}_{\text {sulfate }}$ shifts over 494 relatively short stratigraphic intervals, and a general positive coupling between $\delta^{13} \mathrm{C}_{\text {carbonate }}$ and $495 \delta^{34} S_{\text {sulfate }}$ all suggest that the Middle to Late Cambrian sulfate reservoir was more sensitive to 496 change than either terminal Neoproterozoic or Cenozoic oceans.

A simple C and S isotope box model illustrates that low sulfate concentrations alone fail

498 to account for the $>10 \% \delta^{34} S_{\text {sulfate }}$ shifts recognized in the Port au Port Group strata. These 
499 larger $\delta^{34} \mathrm{~S}$ shifts can be generated if fluctuating oceanic redox is invoked, whereby marine 500 anoxia forces reduced C/S and elevated $\Delta^{34} \mathrm{~S}$, resulting in larger $\delta^{34} \mathrm{~S}$ changes per mole of OC 501 buried. The emerging environmental picture of the later Cambrian Earth system suggests that 502 the delayed recovery of organisms with carbonate skeletons and animal reefs following late 503 Early Cambrian extinction may have been due in part to fluctuating marine redox and reduced 504 oxygen levels in the coupled ocean-atmosphere system.

505 Ultimately, the relationship between the geochemical cycles of $\mathrm{C}$ and $\mathrm{S}$ represent a 506 complex set of feedbacks that operate on a variety of timescales. The Middle to Late Cambrian 507 ocean presents an opportunity to investigate the driving forces behind $\mathrm{C}$ and $\mathrm{S}$ isotopic change in 508 oceans unlike those we know today (i.e., through most of Earth history).

509

\section{Acknowledgements}

511 We thank the Agouron Institute (postdoctoral fellowship to SP) and NSF Grant DES

5120420592 (AHK) for partial funding of this research. We also thank Greg Eischeid and Dan 513 Schrag for assistance with carbon and oxygen isotope analyses and David Fike, an anonymous 514 reviewer and P. Delaney for comments that improved the content and clarity of this manuscript. 515 


\section{References Cited}

517 Ault, W.U. and Kulp, J.L., 1959. Isotopic geochemistry of sulphur. Geochimica et

$518 \quad$ Cosmochimica Acta 16, 201-235.

519 Bambach, R.K., Knoll, A.H. and Wang, S.M., 2004. Origination, extinction, and mass depletions $520 \quad$ of marine diversity. Paleobiology 30, 522-542.

521 Berner, E.K. and Berner, R.A., 1996. Global Environment. Prentice Hall, Upper Saddle River, 522 NJ, 376 pp.

523 Berner, R.A., 1987. Models for carbon and sulfur cycles and atmospheric oxygen: application to $524 \quad$ Paleozoic geologic history. American Journal of Science 287, 177-196.

525 Berner, R.A., 2006. GEOCARBSULF: A combined model for Phanerozoic atmospheric $\mathrm{O}_{2}$ and $526 \quad \mathrm{CO}_{2}$. Geochimica et Cosmochimica Acta 70, 5653-5664.

527 Berner, R.A. and Raiswell, R., 1983. Burial of organic carbon and pyrite sulfur in sediments over 528 Phanerozoic time: a new theory. Geochimica et Cosmochimica Acta 47, 855-862.

529 Berry, W.B.N. and Wilde, P., 1978. Progressive ventilation of the oceans-An explanation for the distribution of the lower Paleozoic black shales. American Journal of Science 278, 257-

532 Böttcher, M.E., Thamdrup, B. and Vennemann, T.W., 2001. Oxygen and sulfur isotope fractionation during anaerobic bacterial disproportionation of elemental sulfur. Geochimica et Cosmochimica Acta 65, 1601-1609.

Brennan, S.T., Lowenstein, T.K. and Horita, J., 2004. Seawater chemistry and the advent of biocalcification. Geology 32, 473-476. 
537 Burdett, J.W., Arthur, M.A. and Richardson, M., 1989. A Neogene seawater sulfur isotope age $538 \quad$ curve from calcareous pelagic microfossils. Earth and Planetary Science Letters 94, 189539198.

540 Canfield, D.E., 2004. The evolution of the Earth surface sulfur reservoir. American Journal of $541 \quad$ Science 304, 839-861.

542 Canfield, D.E., Poulton, S.W. and Narbonne, G.M., 2007. Late Neoproterozoic deep-ocean 543 oxygenation and the rise of animal life. Science 315, 92-95.

544 Canfield, D.E., Raiswell, R., Westrich, J.T., Reaves, C.M. and Berner, R.A., 1986. The use of 545 chromium reduction in the analysis of reduced inorganic sulfur in sediments and shales. $546 \quad$ Chemical Geology 54, 149-155.

547 Canfield, D.E. and Teske, A., 1996. Late Proterozoic rise in atmospheric oxygen concentration 548 inferred from phylogenetic and sulphur-isotope studies. Nature 382, 127-132.

549 Canfield, D.E. and Thamdrup, B., 1994. The production of ${ }^{34}$ S-depleted sulfide during bacterial 550 disproportionation of elemental sulfur. Science 266, 1973-1975.

551 Chow, N. and James, N.P., 1987. Facies-specific, calcitic and bimineralic ooids from Middle and 552 Upper Cambrian platform carbonates, western Newfoundland, Canada. Journal of $553 \quad$ Sedimentary Petrology 57, 907-921.

554 Cowan, C.A. and James, N.P., 1993. The interactions of sea-level change, terrigenous-sediment 555 influx, and carbonate productivity as controls on Upper Cambrian Grand Cycles of 556 western Newfoundland, Canada. Geological Society of America Bulletin 105, 1576$557 \quad 1590$. 
558 Cypionka, H., Smock, A.M. and Böttcher, M.E., 1998. A combined pathway of sulfur compound disproportionation in Desulfovibrio desulfuricans. FEMS Microbiology Ecology 166, 181-186.

Derry, L.A., Brasier, M., Corfield, R., Rozanov, A. and Zhuravlev, A., 1994. Sr and C isotopes in Lower Cambrian carbonates from the Siberian craton: a paleoenvironmental record during the "Cambrian explosion". Earth and Planetary Science Letters 128, 671-681.

Detmers, J., Brüchert, V., Habicht, K.S. and Kuever, J., 2001. Diversity of sulfur isotope fractionations by sulfate-reducing prokaryotes. Applied and Environmental Microbiology

Edwards, D., 1979. The early history of vacular plants based on Late Silurian and Early Devonian floras of the British Isles. In: A.L. Harris, C.H. Holland and B.E. Leake (Editors), The Caledonides of the British Isles-reviewed. Geological Society of London Special Publication, pp. 405-410.

571 Fike, D.A. and Grotzinger, J.P., 2008. A paired sulfate—pyrite $\delta^{34}$ S approach to understanding the evolution of the Ediacaran—Cambrian sulfur cycle. Geochimica et Cosmochimica Acta 72, 2636-2648.

574 Fike, D.A., Grotzinger, J.P., Pratt, L.M. and Summons, R.E., 2006. Oxidation of the Ediacaran Ocean. Nature 444, 744-747.

576 Fischer, W., Higgins, J. and Pruss, S., 2007. Delayed biotic recovery from the Permian-Triassic extinction may have been influenced by a redox-driven reorganization of the marine

579 Garrels, R.M. and Lerman, A., 1984. Coupling of sedimentary sulfur and carbon cycles-an improved model. American Journal of Science 284, 989-1007. 
581 Gill, B.C., Lyons, T.W. and Saltzman, M.R., 2007. Parallel, high-resolution carbon and sulfur

582 isotope records of the evolving Paleozoic marine sulfur reservoir. Palaeogeography, 583 Palaeoclimatology, Palaeoecology 256, 156-173.

584 Given, R.K. and Lohmann, K.C., 1985. Derivation of the original isotopic composition of $585 \quad$ Permian marine cements. Journal of Sedimentary Petrology 55, 430-439.

586 Gorjan, P., Veevers, J.J. and Walter, M.R., 2000. Neoproterozoic sulfur-isotope variation in $587 \quad$ Australia and global implications. Precambrian Research 100, 151-179.

588 Habicht, K.S. and Canfield, D.E., 1997. Sulfur isotope fractionation during bacterial sulfate 589 reduction in organic-rich sediments. Geochimica et Cosmochimica Acta 61, 5351-5361.

590 Habicht, K.S. and Canfield, D.E., 2001. Isotope fractionation by sulfate-reducing natural populations and the isotopic composition of sulfide in marine sediments. Geology 29,

593 Habicht, K.S., Canfield, D.E. and Rethmeier, J., 1998. Sulfur isotope fractionation during 594 bacterial reduction and disproportionation of thiosulfate and sulfite. Geochimica et

596 Habicht, K.S., Gade, M., Thamdrup, B., Berg, P. and Canfield, D.E., 2002. Calibration of sulfate levels in the Archean ocean. Science 298, 2372-2374.

598 Halverson, G.P., Hoffman, P.F., Schrag, D.P., Maloof, A.C. and Rice, A.H., 2005. Towards a 599 600 Neoproterozoic composite carbon isotope record. Geological Society of America Bulletin $117,1181-1207$.

602

Halverson, G.P. and Hurtgen, M.T., 2007. Ediacaran growth of the marine sulfate reservoir. Earth and Planetary Science Letters 263, 32-44. 
603 Hayes, J.M., Strauss, H. and Kaufman, A.J., 1999. The abundance of ${ }^{13} \mathrm{C}$ in marine organic matter and isotopic fractionation in the global biogeochemical cycle of carbon during the past 800 Ma. Chemical Geology 161, 103-125.

606 Higgins, J. and Schrag, D., 2007. $\mathrm{CaCO}_{3}$ cycling in anoxic oceans, Geological Society of America, Abstracts with Programs, pp. 420.

608 Holland, H.D., 1973. Systematics of the isotopic composition of sulfur in the oceans during the 609 Phanerozoic and its implications for atmospheric oxygen. Geochimica et Cosmochimica

611 Holland, H.D., 1984. The Chemical Evolution of the Atmosphere and Oceans. Princeton University Press, Princeton, NJ, 582 pp.

613 Holser, W.T., Maynard, J.B. and Cruikshank, K.M., 1989. Modelling the Natural Cycle of Sulphur Through Phanerozoic Time. In: P. Brimblecombe and A.Y. Lein (Editors), Evolution of the Global Biogeochemical Sulphur Cycle. John Wiley \& Sons Ltd, pp. 2156.

Horita, J., Zimmermann, H. and Holland, H.D., 2002. Chemical evolution of seawater during the Phanerozoic: Implications from the record of marine evaporites. Geochimica et Cosmochimica Acta 66, 3733-3756.

Hough, M.L. et al., 2006. A major sulphur isotope event at c. 510 Ma: a possible anoxiaextinction-volcanism connection during the Early-Middle Cambrian transition? Terra Nova 18, 257-263.

Hurtgen, M.T., Arthur, M.A. and Halverson, G.P., 2005. Neoproterozoic sulfur isotopes, the 625 evolution of microbial sulfur species, and the burial efficiency of sulfide as sedimentary pyrite. Geology 33, 41-44. 
626

627

628

629

630

631

632

633

634

635

636

637

638

639

640

641

642

643

644

645

646

647

Hurtgen, M.T., Arthur, M.A., Suits, N.S. and Kaufman, A.J., 2002. The sulfur isotopic composition of Neoproterozoic seawater sulfate: Implications for a snowball Earth? Earth and Planetary Science Letters 203, 413-430.

Hurtgen, M.T., Halverson, G.P., Arthur, M.A. and Hoffman, P.F., 2006. Sulfur cycling in the aftermath of a 635-Ma snowball glaciation: Evidence for a syn-glacial sulfidic deep ocean. Earth and Planetary Sciences 245, 551-570.

Indermühle, A. et al., 1999. Holocene carbon-cycle dynamics based on $\mathrm{CO}_{2}$ trapped in ice at Taylor Dome, Antarctica. Nature 398, 121-126.

Johnston, D.T. et al., 2005. Active microbial sulfur disproportionation in the Mesoproterozoic. Science 310, 1477-1479.

Jørgensen, B.B., 1990. A thiosulfate shunt in the sulfur cycle of marine sediments. Science 249, $152-154$.

Kah, L.C., Lyons, T.W. and Frank, T.D., 2004. Low marine sulphate and protracted oxygenation of the Proterozoic biosphere. Nature 431, 834-838.

Kampschulte, A. and Strauss, H., 2004. The sulfur isotopic evolution of Phanerozoic seawater based on the analysis of structurally substituted sulfate in carbonates. Chemical Geology 204, 255-286.

Knoll, A. and Carroll, S., 1999. Early animal evolution: emerging views from comparative biology and geology. Science 284, 2129-2137.

Knoll, A.H., 2003. Biomineralization and evolutionary history. In: P.A. Dove, J.D. Yoreo and S. Weiner (Editors), Biomineralization. Mineralogical Society of America, Washington, DC, pp. 329-356. 
648 Kump, L.R. and Arthur, M.A., 1999. Interpreting carbon-isotope excursions: carbonates and organic matter. Chemical Geology 161, 181-198.

650 Kump, L.R. and Garrels, R.M., 1986. Modeling atmospheric $\mathrm{O}_{2}$ in the global sedimentary redox 651 cycle. American Journal of Science 286, 337-360.

652 Kurtz, A.C., Kump, L.R., Arthur, M.A., Zachos, J.C. and Paytan, A., 2003. Early Cenozoic 653 decoupling of the global carbon and sulfur cycles. Paleoceanography 18.

654 Leventhal, J.S., 1983. An interpretation of carbon and sulfur relationships in Black Sea 655 sediments as indicators of environments of deposition. Geochimica et Cosmochimica $656 \quad$ Acta 47, 133-137.

657 Li, X. and Droser, M.L., 1997. Nature and distribution of Cambrian shell concentrations:

658 Evidence from the Basin and Range Province of the Western United States (California, $659 \quad$ Nevada, and Utah). Palaios 12, 111-126.

$660 \mathrm{Li}, \mathrm{X}$. and Droser, M.L., 1999. Lower and Middle Ordovician shell beds from the Basin and 661 Range province of the western United States (California, Nevada, and Utah). Palaios 14, $662 \quad 215-233$.

663 Lowenstein, T.K., Hardie, L.A., Timofeeff, M.N. and Demicco, R.V., 2003. Secular variation in 664 665 seawater chemistry and the origin of calcium chloride basinal brines. Geology 31, 857-

666 Lowenstein, T.K., Timofeeff, M.N., Brennan, S.T., Hardie, L.A. and Demicco, R.V., 2001. 667 Oscillations in Phanerozoic seawater chemistry: Evidence from fluid inclusions. Science $668 \quad 294,1086-1088$. 
Lyons, T.W., 1997. Sulfur isotopic trends and pathways of iron sulfide formation in upper Holocene sediments of the anoxic Black Sea. Geochimica et Cosmochimica Acta 61, 3367-3382.

McFadden, K.A. et al., 2008. Pulsed oxidation and biological evolution in the Ediacaran Doushantuo Formation. Proceedings of the National Academy of Science 105, 31973202.

Mook, W.G., 1986. ${ }^{13} \mathrm{C}$ in atmospheric $\mathrm{CO}_{2}$. Netherlands Journal of Sea Research 20, 211-223.

Paytan, A., Kastner, M., Campbell, D. and Thiemens, M.H., 1998. Sulfur isotopic composition of Cenozoic seawater sulfate. Science 282, 1459-1462.

Paytan, A., Kastner, M., Campbell, D. and Thiemens, M.H., 2004. Seawater sulfur isotope fluctuations in the Cretaceous. Science 304, 1663-1665.

Petrychenko, O.Y., Peryt, T.M. and Chechel, E.I., 2005. Early Cambrian seawater chemistry from fluid inclusions in halite from Siberian evaporites. Chemical Geology 219, 149-161.

Porter, S.M., 2004. Closing the phosphatization window: testing for the influence of taphonomic megabias on the pattern of small shelly fossil decline. Palaios 19, 178-183.

Pruss, S., Finnegan, S., Fischer, W. and Knoll, A., submitted. Carbonates in skeleton-poor seas: New insights from Cambrian and Ordovician strata of Laurentia. Palaios.

Raab, M. and Spiro, B., 1991. Sulfur isotopic variations during seawater evaporation with fractional crystallization. Chemical Geology 86, 323-333.

Raiswell, R. and Berner, R.A., 1985. Pyrite formation in euxinic and semi-euxinic sediments. American Journal of Science 285, 710-724.

Raiswell, R. and Berner, R.A., 1986. Pyrite and organic matter in Phanerozoic normal marine shales. Geochimica et Cosmochimica Acta 50, 1967-1976. 
692 Rees, C.E., Jenkins, W.J. and Monster, J., 1978. The sulphur isotopic composition of ocean 693 water sulphate. Geochimica et Cosmochimica Acta 42, 377-381.

694 Rowland, S.M. and Shapiro, R.S., 2002. Reef patterns and environmental influences in the 695 Cambrian and earliest Ordovician. In: W. Kiessling, E. Flügel and J. Golonka (Editors), 696 Phanerozoic Reef Patterns, Tulsa, pp. 95-128.

697 Saltzman, M.R., 2005. Phosphorus, nitrogen, and the redox evolution of Paleozoic oceans. $698 \quad$ Geology 33, 573-576.

699 Saltzman, M.R. et al., 2004. The Late Cambrian SPICE event and the Sauk II-Sauk III 700 regression: New evidence from Laurentian basins in Utah, Iowa and Newfoundland. $701 \quad$ Journal of Sedimentary Research 74, 366-377.

702 Saltzman, M.R. et al., 2000. A global carbon isotope excursion (SPICE) during the Late 703 Cambrian: relation to trilobite extinctions, organic-matter burial and sea level. 704 Palaeogeography Palaeoclimatology Palaeoecology 162, 211-223.

705 Schröder, S., Schreiber, B.C., Amthor, J.E. and Matter, A., 2004. Stratigraphy and environmental 706 conditions of the terminal Neoproterozoic-Cambrian Period in Oman: evidence from 707 sulphur isotopes. Journal of the Geological Society, London 161, 489-499.

708 Scott, C. et al., 2008. Tracing the stepwise oxygenation of the Proterozoic ocean. Nature 452, $709 \quad 456-459$.

710 Shen, Y., Knoll, A.H. and Walter, M.R., 2003. Evidence for low sulphate and anoxia in a mid711 Proterozoic marine basin. Nature 423, 632-635.

712 Strauss, H., 1999. Geological evolution from isotope proxy signals-sulfur. Chemical Geology 713 161, 89-101. 
714 Trotter, J.A., Williams, I.S., Barnes, C.R., Lécuyer, C. and Nicoll, R.S., 2008. Did cooling

715 oceans trigger Ordovician biodiversification? Evidence from conodont thermometry.

$716 \quad$ Science 321, 550-554.

717 Turchyn, A.V. and Schrag, D.P., 2004. Oxygen isotope constraints on the sulfur cycle over the 718 past 10 million years. Science 303, 2004-2007.

719 Veizer, J., Holser, W.T. and Wilgus, C.K., 1980. Correlation of ${ }^{13} \mathrm{C} /{ }^{12} \mathrm{C}$ and ${ }^{34} \mathrm{~S} /{ }^{32} \mathrm{~S}$ secular 720 variations. Geochimica et Cosmochimica Acta 44, 579-587.

721 Zhuravlev, A. and Wood, R., 1996. Anoxia as the cause of the mid-early Cambrian (Botomian)

722 extinction event. Geology 24, 311-314. 
723 Figure 1. The response of $\delta^{13} \mathrm{C}_{\text {carbonate }}$ and $\delta^{34} \mathrm{~S}_{\text {sulfate }}$ to a $50 \%$ increase in organic carbon and pyrite burial for 1 m.y. As a result of increased pyrite burial, sulfate concentrations fell from 28.0 to $27.8 \mathrm{mM}$. Pre-perturbation mass and isotope compositions were adopted from Kurtz et al. (2003) and approximate the Cenozoic C and S cycles at

728

Figure 2. Stratigraphic column and geochemical data for the March Point and Petit Jardin steady-state.

Figure 3. Compilation of Ediacaran-Ordovician $\delta^{13} \mathrm{C}_{\text {carbonate }}$ (Halverson et al., 2005; Derry et al., 1994; Hayes et al., 1999; Saltzman 2005) and $\delta^{34} S_{\text {sulfate }}$ (Hurtgen et al., 2002; Kampschulte and Strauss, 2004; Fike et al., 2006) and $\delta^{34} S_{\text {pyrite }}$ (Canfield and Teske, 1996; Gorjan et al., 2000; Schöder et al., 2004; Hurtgen et al., 2006; Fike et al., 2006).

Figure 4. $\delta^{34} S_{\text {sulfate }}$ response to a stepwise, $50 \%$ increase in $F_{\text {py }}$ for 1 m.y. (from 2 to 3 m.y. and represented by gray band) under varying initial sulfate concentrations $(0.28 \mathrm{mM}, \tau=$

742 Figure 5. $\delta^{34} S_{\text {sulfate }}$ response to a stepwise, $100 \%$ increase in $F_{\mathrm{py}}$ and $10 \%$ increase in $\Delta^{34} \mathrm{~S}$ 0.27 m.y.; $1.9 \mathrm{mM}, \tau=1.80$ m.y.; and $2.5 \mathrm{mM}, \tau=3.33$ m.y.). (from 25 to 35\%) for 1 m.y. (from 2 to 3 m.y. and represented by gray band) under varying initial sulfate concentrations ( $0.70 \mathrm{mM}, \tau=0.67$ m.y.; $2.1 \mathrm{mM}, \tau=2.00$ m.y.; and $3.5 \mathrm{mM}, \tau=3.33$ m.y.). 


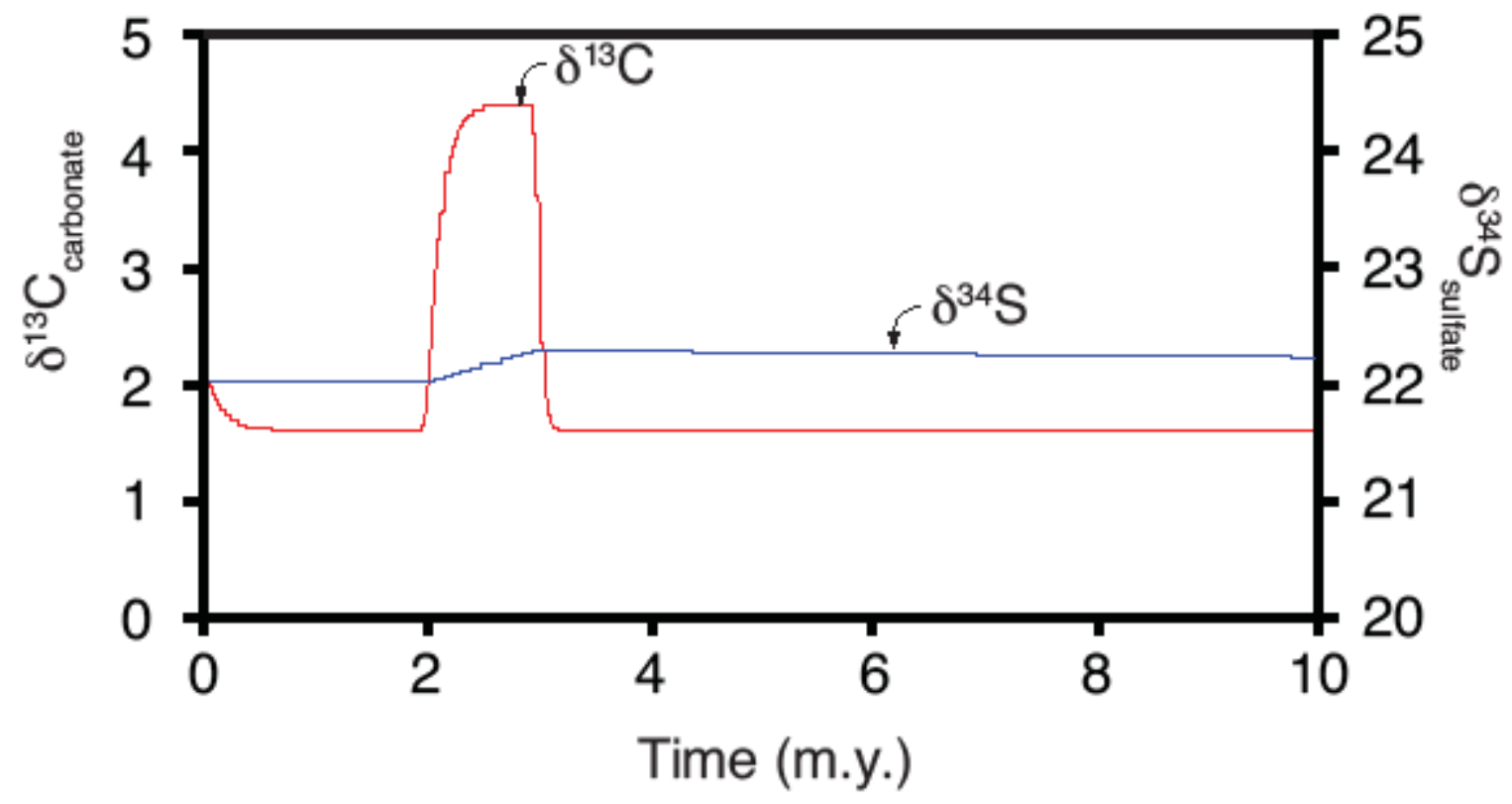

Figure 1, Hurtgen et al. 


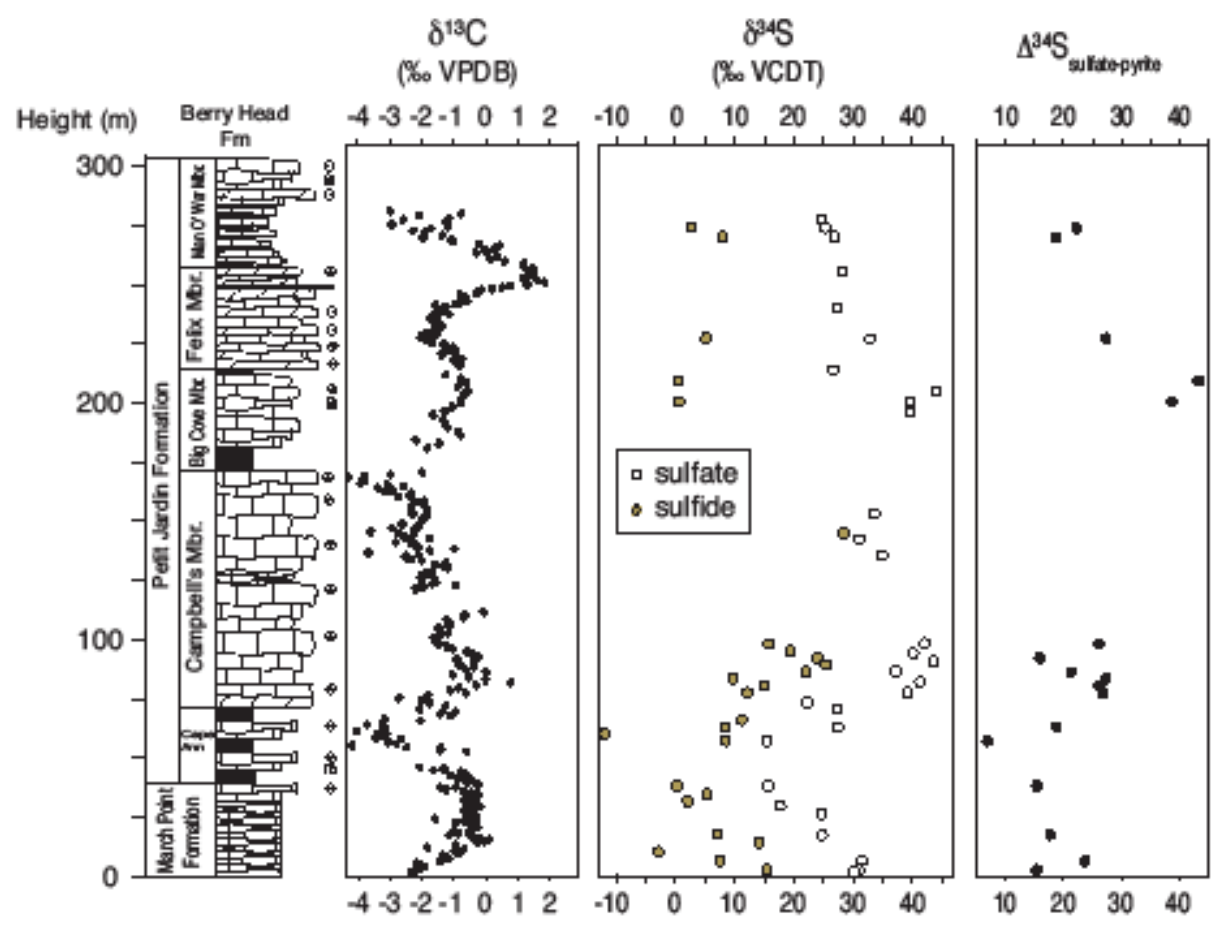

Figure 2, Hurtgen et al. 


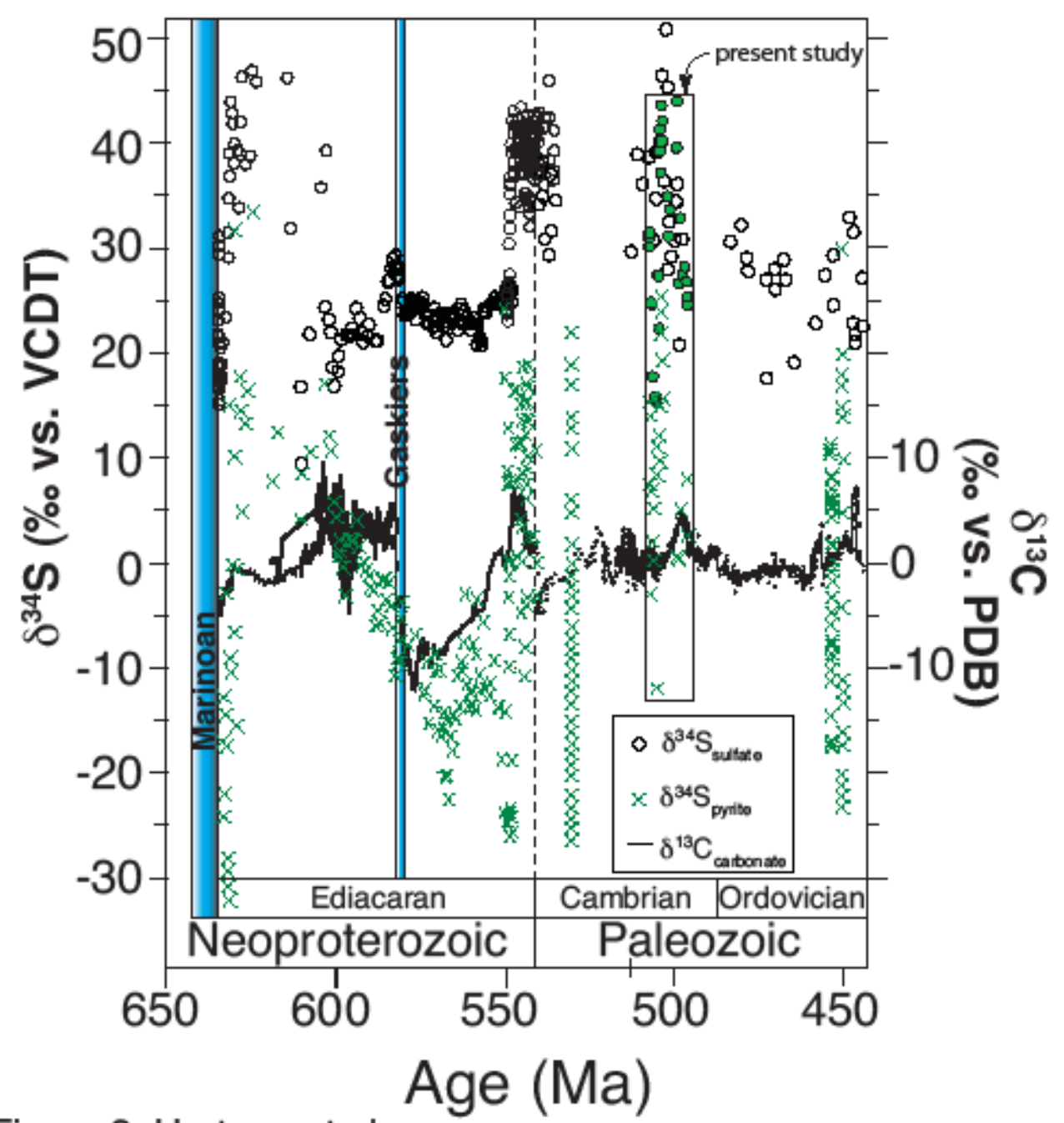

Figure 3, Hurtgen et al. 


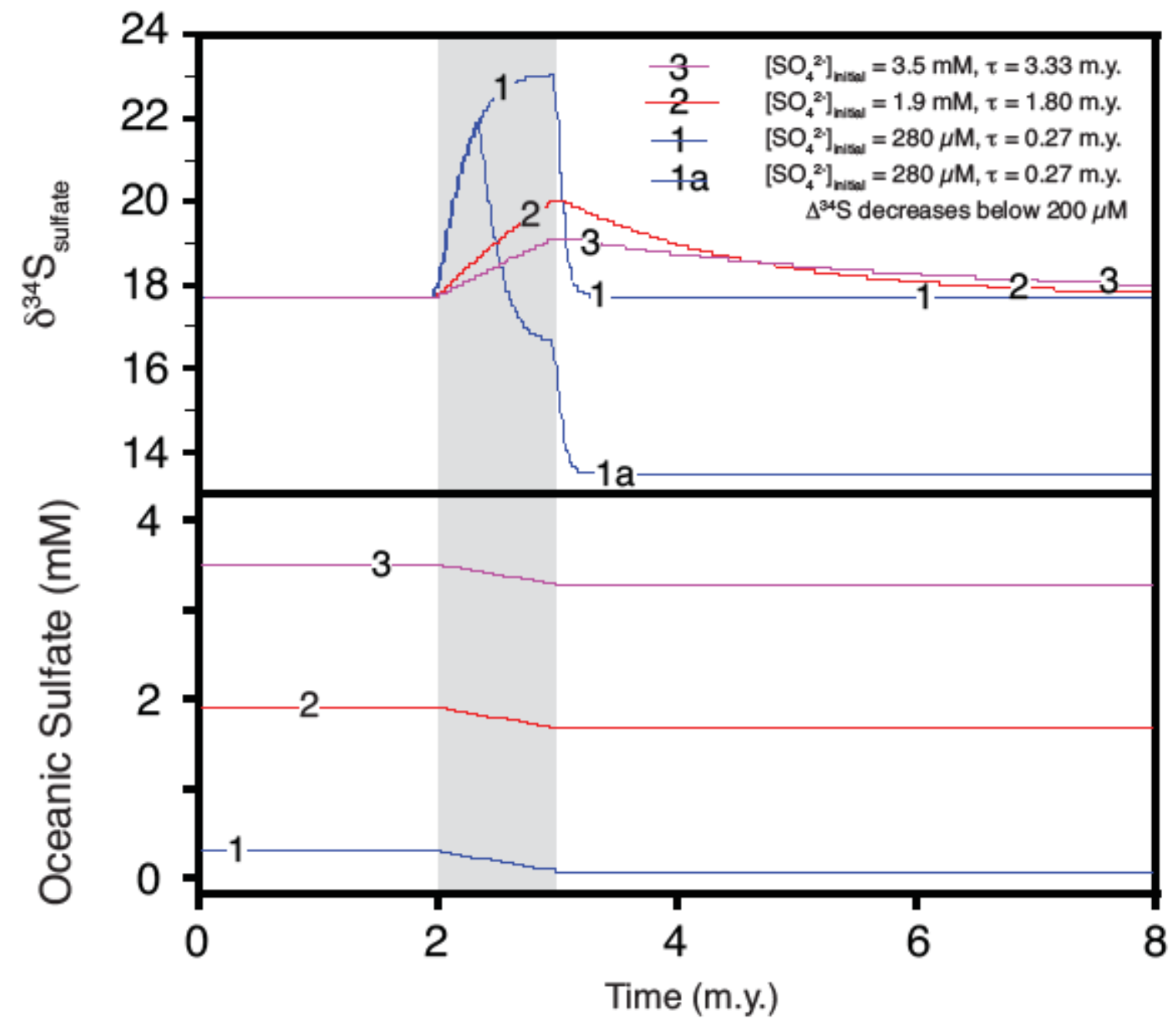

Figure 4, Hurtgen et al. 


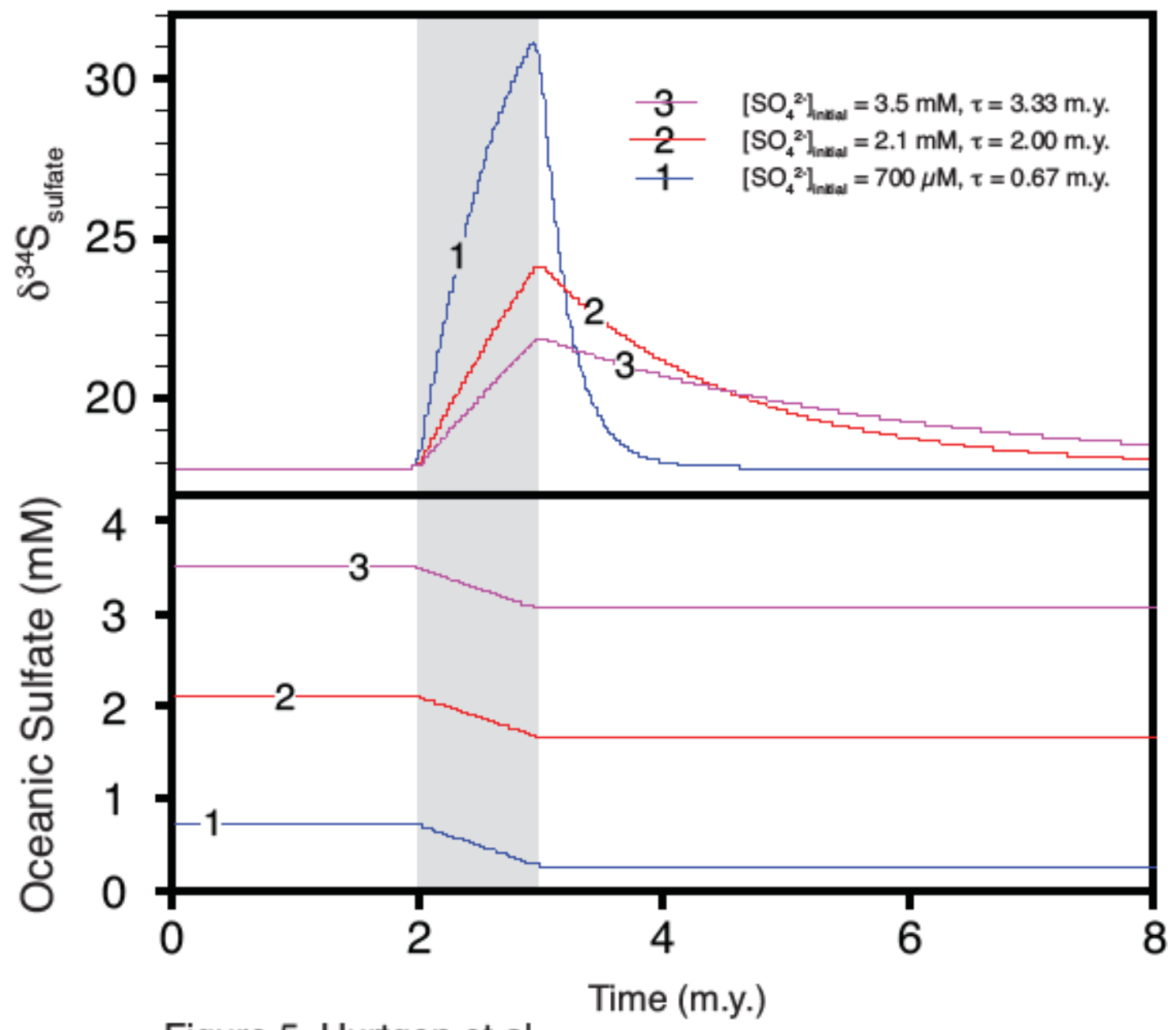

Figure 5, Hurtgen et al. 